\title{
THE IMPACT OF ORGANIZATIONAL CRISIS PREPAREDNESS ON FIRM BUSINESS PERFORMANCE
}

\section{MJERENJE UTJECAJA ORGANIZACIJSKE KRIZNE PRIPREMLJENOSTI NA USPJEŠNOST POSLOVANJA PODUZEĆA}

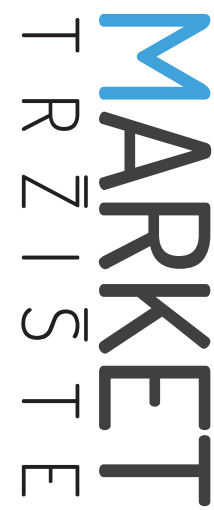

\author{
Market-Tržište \\ Vol. 29, No. 1, 2017, pp. 75-92 \\ UDK 005.334:65.011.4 \\ DOI http://dx.doi.org/10.22598/mt/2017.29.1.75 \\ Preliminary communication
}

\section{Davor Labaš}

Faculty of Economics and Business, University of Zagreb, Trg J. F. Kennedyja 6, 10000 Zagreb, CROATIA, dlabas@efzg.hr

\begin{abstract}
Purpose - Organizations which are crisis prepared are generally considered better equipped to anticipate, detect, manage and make adequate decisions in times of crisis. Therefore, organizational crisis preparedness has strategic importance and significant influence on business. Additionally, very successful organizations are to a large extent crisis prepared, which implies the existence of close ties between general business success and organizational crisis preparedness. Hence, it is of managerial interest to gain insight into whether organizational crisis preparedness can be considered an important determinant of business success. This study aims to empirically explore the importance of medium and large sized firms' organizational crisis preparedness and subsequent impact on their business success. Moreover, it aims to determine whether current organizational crisis preparedness and prospective organizational crisis preparedness statistically significantly influence firm's organizational performance, measured through its two dimensions business efficiency and business effectiveness.
\end{abstract}

Design/Methodology/Approach - This study applies variance-based structural equation modeling PLS SEM on a set of empirically gathered results from a primary research survey.

Findings and implications - This paper empirically confirmed the existence of statistically significant positive impact of organizational crisis preparedness on the business success.

\section{Sažetak}

Svrha - U literaturi iz kriznog menadžmenta postoji mišljenje da što su više poduzeća pripremljena na krize, efikasnija su i u procesu donošenja odluka. Organizacije koje su pripremljene na krize općenito se smatraju kvalitetnije opremljenima za anticipiranje problema, detektiranje i upravljanje u vrijeme krize. Stoga organizacijska krizna pripremljenost ima strateški značaj i bitan utjecaj na poslovanje. Dodatno, veoma uspješne organizacije u velikoj su mjeri pripremljene na krize, što implicira postojanje uske povezanosti između općeg uspjeha poslovanja i organizacijske krizne pripremljenosti. Stoga je u interesu menadžera spoznati može li se organizacijska krizna pripremljenost smatrati značajnom determinantom poslovnog uspjeha. Ova studija namjerava empirijski istražiti značaj i utjecaj organizacijske krizne pripremljenosti na poslovni uspjeh srednjih i velikih poduzeća. Namjerava se utvrditi utječu li sadašnja i buduća organizacijska krizna pripremljenost statistički signifikantno na organizacijski uspjeh, mjeren putem dviju dimenzijaposlovne efikasnosti i poslovne efektivnosti.

Metodološki pristup - Kako bi se testirale navedene relacije, ova studija primjenjuje varijančno bazirano modeliranje strukturnih jednadžbi PLS SEM na nizu primarnih empirijski podataka prikupljenih anketnim istraživanjem.

Rezultati i implikacije - Ovaj rad, baziran na temeljitom teorijskom istraživanju literature, empirijski je potvrdio postojanje statistički signifikantne pozitivne re- 
Limitations - Research sample size is adequate; however, it comprises multiple industries and does not fully reflect specific measures of organizational crisis preparedness of each single industry.

Originality - Research provides interesting insight into the inadequately empirically explored concept of crisis management, along with providing recommendations for managers.

Keywords - crisis management, organizational crisis preparedness, business success, PLS-SEM, business crisis lacije organizacijske krizne pripremljenosti i poslovnog uspjeha.

Ograničenja - Uzorak istraživanja je veličinom adekvatan, no sastoji se od više različitih djelatnosti te ne odražava specifične mjere organizacijske krizne pripremljenosti za svaku pojedinu djelatnost.

Doprinos - Rad pruža zanimljiv uvid u nedovoljno empirijski istražen koncept kriznog menadžmenta, a uz pružanje preporuka za menadžere.

Ključne riječi - krizni menadžment, organizacijska krizna pripremljenost, poslovni uspjeh, PLS-SEM, poslovna kriza 


\section{INTRODUCTION}

Crisis represents a process of transformation caused by severe discontinuities which results in restructuring of social norms and environmental systems (Shaw, Hall, Edwards \& Baker, 2007, p. 562). Moreover, organizational crisis is a result of organizational imperfections inherent within the organizational culture and managerial ignorance which allow the firm's weaknesses to surface and subsequently develop into crisis (Roux-Dufort, 2009, p. 4). Crises are known for lack of adequate information, time constraints, and a necessity to react and adapt to change (Wooten \& James, 2008, p. 367). Organizational crisis can manifest itself in diverse forms and can be precipitated by various different factors (Elsubbaugh, Fildes \& Rose, 2004, p. 112; Lee, Woeste \& Heath, 2007, p. 336); thus, crisis may be caused by a product recall, management or employees errors, technical failures, political events, financial debacles, labor strikes, insider trading, sabotage, violation of safety standards, or acts of nature to name a few calamities, meaning that there is no single general crisis definition or unified means of mastering the crisis (Pearson \& Sommer, 2011, p. 27-28).

The definition of crisis management considers the implementation of systems within an organization to deal with potential crises (Capstone Encyclopaedia of Business, 2003). A more encompassing and one of the best known definitions of crisis management states that: "organizational crisis management is a systemic attempt by organizational members with external stakeholders to avert crises or to effectively manage those that do occur" (Pearson \& Clair, 1998, p. 61). The broader crisis management approach and definition, which is assumed in this paper and accepted by a number of scientists in the field, includes the concepts of crisis prevention and preparation while embracing strategic planning perspective and examination of far-reaching crisis effects (Parnell, Koseoglu \& Spillan, 2010, p. 109). Hence, the research on corporate crises and how firms prepare and handle such events can all be classified under the term crisis management (Hale, Dulek \& Hale, 2005, p. 113).

In this research study, effective crisis management is defined as the ability to meet an organization's strategic and tactical objectives (Shaw, 2004, p. 37). It is characterized by the ability to make "sound and rapid decisions under pressure" (Wooten \& James, 2008, p. 367). Organizations which do have crisis management are better equipped to anticipate, detect, and manage in times of crisis, whereas effective crisis management means proper handling, persistent policies, and retention of the firm's credibility in business crisis times (Sapriel, 2010, p. 29). Put simply, effective crisis management is deemed efficient when business momentum is assured and core competencies are sustained (Pearson \& Clair, 1998, p. 60-61). Therefore, two approaches to a general crisis management exist in the literature: a proactive approach to a crisis management model and a reactive approach (Lalonde, 2007, p. 21; Spillan, Parnell \& Mayolo, 2011, p. 63). The difference is in the notion that, by acting pro-actively, the firm has a higher chance to prevent or better manage the crisis once it occurs (Lee et al., 2007, p. 334).

Looking back, organizational crisis readiness (preparedness) is a term coined by Reilly in 1987 that initially defined as organizational flexibility in times of uncertainty caused by crisis (Reilly, 1987, p. 80-81). Organizational crisis preparedness, according to Light (2008, p. 17), can be understood as a proactive orientation to crisis, i.e. effectively handling the changes and uncertainty caused by crisis. Organizational crisis preparedness has a goal of reducing known risks (Selart \& Johansen, 2013, p. 100). Accordingly, organizational crisis preparedness in this paper will be defined as an activity which reduces stress from sudden surprises and improves the capabilities of organization to cope with crisis (Rousaki \& Alcott, 2007, p. 30).

The link between the area of marketing and crisis preparedness and its importance can be found in the notion that crisis preparedness impacts crisis reputation. Since crisis can be a threat to a 


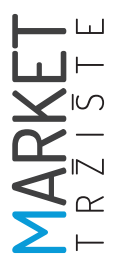

brand and organizational reputation, crisis preparedness and building a positive pre-crisis reputation helps protect and shield an organization in the times of crisis (Coombs \& Holladay, 2006). Reputation management serves a purpose of preventing organizational crisis, and improving organizational preparedness and response to crisis. Reputation management enables more effective crisis management and improved reputation (Tucker \& Melawar, 2005, p. 386). For instance, plans for crisis management communication are considered an elementary component of organizational crisis preparedness, coupled with marketing efforts, which help marketers rebuild lost positive image with lower costs for the organization (Ritchie, 2004, p. 677). Furthermore, crisis preparedness, through its environmental scanning and assessment activities, helps assess and manage the organizational brand reputation threats and crisis (Greyser, 2009). In addition, marketing activities can also be seen as helpful post-crisis activities and reactive crisis management measures for restoring trust and building corporate reputation (Pforr \& Hosie, 2008, p. 251).

Furthermore, in the organizational crisis preparedness literature, which stresses the proactive approach, researchers in their predominantly qualitative studies paid significant attention to crisis planning and analysis with respect to its effects on business success (Fink, 1986; Smith, 1990; Hale et al., 2005; Lalonde, 2007), as well as through the use of case studies, which lack the possibilities of generalization of results (Carmeli \& Schaubroeck, 2008, p. 188-189). For a long time, theoretical aspects of organizational crisis preparedness and its influence on business success were assumed, but were not sufficiently empirically tested. Several authors have found through research conducted that organizational crisis preparedness has strategic importance and significant influence on business, which is mainly the result of an adequate existing crisis preparedness culture and firm's values (Pearson \& Clair, 1998; Coutu, 2002). For instance, a positive correlation was found between perceived level of organizational crisis preparedness and business success (Carmeli \& Schaubroeck, 2008). Moreover, Light (2008, p. 51-54) considered organizational crisis preparedness one of the key attributes of organizational success and excellence; a positive influence of organizational crisis preparedness on business success was among other findings noted, and it was indicated that successful performance of organizations is one of the more significant predictors of crisis prepared firms, i.e. the correlation was noted, but was not directly tested in the developing countries.

However, even though research and development of the crisis management field and, in particular, the organizational crisis preparedness is noted, there are still challenges and room for numerous improvements in the organizational crisis preparedness research (Fowler, Kling \& Larson, 2007, p. 89; Sapriel, 2010, p. 29). Current organizational crisis preparedness guidelines are neither encompassing nor complete; therefore, there is a need for additional research and adjustment (Shaw, 2004, p. 42). Accordingly, in the aftermath of recent global world economic crisis it is of interest to researchers, stakeholders, and managers to stress, empirically analyze, and determine the importance of organizational crisis preparedness on the overall business success. The stated relationship is interesting to explore and understand since the managerial perceptions of crisis and crisis preparedness can be different in developing countries from those in developed ones (Parnell et al., 2010, p. 114). Moreover, crisis management differences between these two groups of countries can be attributed to a certain extent to strategy (greater managerial perceived external risks in developing countries) and cultural differences (Spillan et al., 2011, p. 58-59). Accordingly, the scientific contribution of this exploratory paper is achieved by researching crisis preparedness activities, analysis, and synthesis of recent scientific and professional literature, coupled with the empirical analysis of theoretical concepts and better understanding of organizational crisis prepared- 
ness and its impact on business performance in a developing country. It will provide an empirically based answer to the question whether current and prospective crisis preparedness in medium and large-sized firms in developing countries also positively impacts performance (measured through its two dimensions - business efficiency and business effectiveness), as posited in the research in developed countries.

The remainder of the article is organized as follows: Section 2 reviews the literature regarding organizational crisis preparedness and business success. Section 3 describes the methodology, i.e. research goals, data, and sample, and presents the applied analytical approach and variable operationalization. In Section 4, data is analyzed and key results are presented, along with a discussion. Finally, Section 5 of this paper concludes with several important theoretical and managerial implications and recommendations.

\section{LITERATURE REVIEW}

In order to define the approach and variables for the measurement instrument, it is necessary to evaluate previous findings. According to a study conducted by Parnell and others (2010, p. 111), important variables of organizational crisis preparedness which enable a rapid response to crisis events include: previous crisis experience, organizational communication, organizational culture, organizational planning, and the availability of resources, which could help in the prevention of crisis. In their empirical study, Rousaki and Alcott (2007, p. 27-37) conduct an analysis of the determinants of influence on organizational crisis preparedness: organizational size, previous crisis experience, and connection with the levels of crisis management and crisis readiness. Researchers observed a crisis management plan, access to resources, and fast response to crisis to be significant crisis management activities, along with past crisis experience, which has proved to be helpful in improving organizational crisis preparedness; meanwhile, organizational size was found to weakly influence improvements in organizational crisis preparedness. Furthermore, according to the results of research done by Spillan and others (2011, p. 76), strategic planning has influence on organizational crisis preparedness. Focus on continuous improvements is an important organizational crisis preparedness and business success measure, which was additionally tested in a research done by Carmeli and Schaubroeck (2008, p. 189). It is worth noting that business success is not an unequivocally determined term in the literature. In addition, with a significant shift of firm's orientation to non-financial aspects of business, firms have shifted their focus on long-term from short-term success (Kunc \& Bhandari, 2011, p. 1346). It can also be argued that the more crisis prepared firms are, the more efficient their decision-making process is (Valackie, 2010, p. 104).

Furthermore, according to research survey results by Elsubbaugh and others (2004, p. 115), the most common organizational crisis preparedness activities are as follows:

1. Spreading of positive organizational culture which can help crisis management (values and concepts), 96.5\%;

2. Detection of early warning signal changes, 94.8\%;

3. Creation of efficient information flow $94.7 \%$;

4. Mobilization and implementation of resources, 81.0\%;

5. Acceptance of crisis management as a strategic determinant, 67.2\%; and

6. Improving the speed of decision making, $41.4 \%$.

More specifically, recommendations are as follows.

In order to improve organizational crisis preparedness, it is recommended to form a flexible crisis management team within the organization, conduct sensitivity analysis, as well as ensure a continuous formal and informal training of employees. In addition, Probst and Raisch (2005, p. 99) considered that crisis management

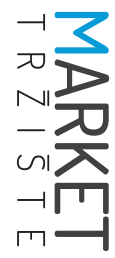


should primarily be aligned with the overall business strategy. Sometimes, in order for crisis management to be successful, a transformation of the existing organizational culture and a reform of management is needed (Mikušova \& Horvathova, 2011, p. 614). A successful approach towards organizational crisis preparedness requires communication of crisis plans to employees; not only can such communication have a positive influence on their morale and motivation in times of crisis, it also sends a positive, reinforcing message to employees that crises are predictable and that they can be controlled by competent management and, consequently, reduces the anxiety connected with changes and uncertainty caused by crisis (Selart \& Johansen, 2013, p. 100-104). Accordingly, even though sometimes managers do not wish to think about the crises, they should be aware of the level of existing risks, crises prevention, and protection of organizational reputation. These are the areas where organizational crisis preparedness has a significant role, as opposed to a mere crisis response when crisis strikes. However, in order to establish such an environment, as noted by Jaques (2010, p. 14), organizational changes need to occur in the following four domains:

1. Identification of potential causes of crisis;

2. Implementation of effective mechanisms of crisis signals detection and response to changes;

3. Timely notification of stakeholder groups and their goals;

4. Implementation of systemic organizational learning.

When defining business success from the organizational crisis preparedness perspective, moderating variables, such as the years of business experience, previous crisis experience (James, Wooten \& Dushek, 2011, p. 461; FEMA, 2011, p. 14), and firm's size, should also be included. Since larger organizations are more complex and require integration and coordination along the departments with respect to planning, it is considered and we can posit a positive influ- ence of increasing firm size regarding planning and, accordingly, stronger managerial perceptions of organizational crisis preparedness and awareness (Rousaki \& Alcott, 2007, p. 31). Hence, first moderating variable used in this research is organizational size, since it is posited that larger firms have higher possibility of having in place crisis management personnel and teams for coordination and planning of crisis management efforts. Another significant moderator which affects the organizational crisis preparedness included in this research is previous crisis experience: it has a positive impact on future response to crisis situations, encourages crisis thinking and considering of possible crisis situations which, in turn, open up new possibilities for learning from crises and debunking the myths of invulnerability of the organization (Reilly, 1993, p. 139; Wooten \& James, 2008, p. 353; Jaques, 2010, p. 14). Learning from the mistakes and crisis is a vital activity, especially from the aspect of organizational learning and adjustment, whereas the crisis is at the same time the best incentive for developing organizational crisis preparedness. In other words, crisis experience is an important determinant of organizational success (Parnell et al., 2010, p. 112). Veil (2011, p. 129-130) claims that it is beneficial to a certain extent to experience a mild type of crisis in order for firms to become more resilient because success sends a signal that no changes are needed and, consequently, no organizational learning takes place. The organizations which have experienced and gone through a more significant crises in order to step away from their present dominant way of thinking change their top management, thus enabling new directions and development of ideas which signalize changes (Nystrom \& Starbuck, 1984, p. 53). Organizational learning occurs when individuals exchange knowledge through interaction with other groups of individuals. In that way, employees can learn from the organization and achieve a process of knowledge exchange among individuals, groups, and organizations (Santos-Vijande, Lopez-Sanchez \& Trespalacios, 2012, p. 1080). Learning from previous crises is considered useful if a firm takes 
measures to prevent the occurrence of past crisis (James et al., 2011, p. 474). Therefore, in the organizations which are prepared for crises, organizational learning takes place and subsequently increases the level of preparedness for future crises (Fowler et al., 2007, p. 90). Such organizations are more flexible and aware of potential threats, and have a higher level of preparedness (Carmeli \& Schaubroeck, 2008, p. 189). After empirically testing the two dichotomous categorical moderating the variables of organizational size and previous crisis experience, no statistically significant differences were found between the large and medium-sized firms' influence on organizational crisis preparedness, or between the firms which have experienced previous crisis and the ones that had not regarding the influence of such experience on organizational crisis preparedness.

Moreover, business success is considered an adequate measure for the evaluation of crisis management effectiveness (Wang, 2008). Business success is considered a complex construct, influenced by numerous organizational dimensions, and to a significant extent reflects the capabilities of top management, which through the effects of external and internal processes have considerable effect on the organization. Accordingly, a multidimensional perspective which includes the effectiveness and efficiency of business success measures is needed. Defining a variation in business success is one of the lasting themes of organizational crisis preparedness; in the majority of research, it is defined as an independent variable, determined by variables which cause the variations in business success (March \& Sutton, 1997, p. 698-702). Therefore, business success was selected as an indicator for the evaluation of crisis management strategies, as it is universally accepted that organizational success represents a key measure of business effectiveness. A number of studies in crisis management were conducted with the aim of improving organizational performance through the use of crisis management concepts (Wang, 2008, p. 1).
Leading authorities in the crisis management field (Fink, 1986; Pearson \& Clair, 1998) have also, in their theoretical constructs of model, considered and claimed organizational success to be a dependent variable and a result of crisis management. Furthermore, research by Parnell and others (2010, p. 111) explored the relationship between organizational crisis and internal functionality / aspects of organizational crisis preparedness, where a positive association was noted. Considering previous research, we can adopt the assumption that business success is an effective measure of organizational crisis preparedness (Wang, 2008, p. 1). Accordingly, it is expected that organizations will have a higher level of business success as a result of effective crisis preparedness.

\section{METHODOLOGY AND MODEL}

The modeling method and the research survey method approach were used as the elementary instruments of primary research. An organizational level, cross-sectional study was applied, along with a diverse, cross-industry and representative sample online research survey, with self-reported data and key respondent approach. Board members and senior managers were target respondents due to their understanding of organizational crisis preparedness and competences to respond to questions regarding strategy and business success (Santos-Vijande et al., 2012, p. 1083). A total of 1,040 e-mails with a request to participate in the online research survey were sent to appropriate addresses of medium and large-sized firm's board members and senior managers. The firms in the sample were chosen from the Croatian Financial Agency (FINA) national register of business entities (www.fina.hr) by using the random numbers generator method in the SPSS statistical program from a list of all medium-sized $(=1,292)$ and large $(=359)$ firms conducting their business in Croatia in the period from January to December 2012. Out of a total population of

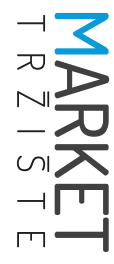




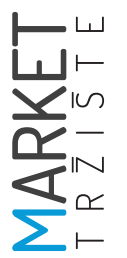

$\mathrm{N}=1,651$ firms, which constituted the research framework, 1,040 firms were selected in the final sample; according to the proportional allocation of two stratums, it included =811 medium-sized firms, and = 229 large firms. After sending two reminders and leaving out partially completed surveys, 114 fully-completed research surveys were gathered from September to December of 2013 , representing a response rate of $11 \%$. The sample size was adequate for the use of PLSSEM methodology and guidelines on adequacy of sample for conducting PLS-SEM analysis and hypothesis testing (Hair, Sarstedt, Ringle \& Mena, 2012, p. 420). Furthermore, PLS-SEM is especially suitable for exploratory research (such as this one) and research which has as its goal explaining the variance of dependent variables for developing theoretical models, which are in an early phase of theoretical development and have not yet been fully accepted in scientific literature (Anderson \& Gerbing, 1988, p. 412; Wilden, Gudergan, Nielsen \& Lings, 2013, p. 78). PLS-SEM is based on a causal approach to modeling and explaining the variance of endogenous latent variables (Guderang, Ringle, Wende \& Will, 2008, p. 1238; Hair, Ringle \& Sarstedt, 2011, p. 139). PLS-SEM does not depend on the distribution of gathered data and is robust in relation to asymmetry and data multicollinearity (Haenlein \& Kaplan, 2004, p. 291). In comparison to covariance based structural equations modeling (CB-SEM), PLS-SEM can analyze smaller samples, more complex models, and has less restrictive conditions than the CB-SEM for the analysis (for instance, it allows analysis of constructs which comprise only 1 or 2 indicators) (Hair et al., 2011, p. 140).

PLS-SEM, as a multivariate analysis method, is used as an alternative to CB-SEM in the situations where is a limited number of research participants and where the data point to a deviation from normal distribution (Wetzels, Oderken-Schroder \& van Oppen, 2009, p. 180; Monecke \& Leisch, 2012, p. 1; Wong, 2013, p. 3). The usual reasons for using the PLS-SEM method are (Hair et al., 2012, p. 420): o

- $\quad$ relatively small sample size as compared to the CB-SEM method;

- it explains variance of endogenous constructs;

- exploratory research and theory development;

- prediction (explaining variance) in the context of developing inadequately explored theories and models for which new information is gathered.

In other words, with an aim of identifying key determinants and predicting key dependent variable, through the exploratory approach to research of constructs with a smaller sample and non-normal distribution, PLS-SEM is a logical choice of methodology for the analysis of the proposed structural model.

Business success was measured through previously constructed and additionally modified instruments, that is, two reflective indicator sets - efficiency and effectiveness indicators, which were measured through self-evaluation of business success through a self-administered research survey answered by managers, comparing and ranking perceived measures of business success to those of their direct competitors within the last three years.

In order to comprehensively define the organizational success, several measures of success should be accounted for. The reasons for using several indicators of business success lies in the fact that business success can be manifested in effectiveness (e.g. growth of market share or growth in sales), as well as efficiency (e.g. return on assets (ROA) or increase in net gains). In such situations, it is possible for a firm to have positive results in both dimensions, only one, or in none of the dimensions (Auh \& Menguc, 2005, p. 1654). Furthermore, it is worth noting that one-dimensional indicators of business success can be biased (Raisch \& Birkinshaw, 2008, p. 400). Therefore, in order to successfully measure business success and influence of organization- 
al crisis preparedness on business success, in this research the respondents were asked to rate and compare how well their firms have conducted business in relation to their key competitors within the last three years. In their work based on Kraft (1990), Santos-Vijande and others (2012, p. 1083) state that direct comparison with key competitors reduces the effects of specific industries in which firms conduct business, reduces the subjectivity of evaluation, and allows for references towards which comparisons can be made.

Accordingly, in defining survey variables, the latent second-degree construct of firms' business success consists of two first-degree latent constructs:

\section{Effectiveness indicators and}

2. Efficiency indicators.

A Likert-type scale, as constructed by Auh and Menguc (2005) based on a verified scale of McDougall, Covin, Robinson and Herron (1994), was used for measuring business success. Respondents were asked to evaluate the business of their firm within the last three years (or in case that the firm is younger than three years, since the date of its founding) according to the categories of business success in relation to their main competitors within the industry, where 1 denominates significantly worse, and 5 significantly better (Auh \& Menguc, 2005, p. 1656). Accordingly, in this paper the five-point Likert scale was used for both dimensions, where $1=1 \mathrm{com}$ pletely disagree, 2 = | disagree, $3=$ | neither agree nor disagree, $4=1$ agree, $5=\mid$ completely agree. Variable business effectiveness was measured through 4 stated questions as determined by the initial scale which were evaluated by means of factor analysis (used for scale validity verification) and confirmed to belong to the same measurement variable, with variable business efficiency (which was measured through 3 stated questions) also determined to have adequate factor structure (Auh \& Menguc, 2005, p. 1657). In addition, an increase in the return on sales (ROS) was used as one of the measures indicative of efficiency. ROS evaluates how well the firm does on the market and how much it depends upon the introduction of new products/ services, as well as adequate choice and segmentation of customers, and satisfying their preferences (Ravichandran \& Lertwongsatien, 2005, p. 255).

According to the literature review conducted, key indicators for measuring efficiency in this paper are: net gain, return on assets (ROA), return on sales (ROS), and return on investments (ROI) (Auh \& Menguc, 2005, p. 1654; Carmeli \& Schaubroeck, 2008, p. 185; Spillan et al., 2011, p. 74; Kunc \& Bhandari, 2011, p. 1347). The respondents' responses in previously conducted research have proved to be very similar to the results of analyzed financial reports; therefore, the proposed approach to the evaluation of business success through self-evaluation by managers is considered valid (Dawes, 1999, p. 67-68). This approach to measurement is considered more suitable for an inter-industry sample, which is the case in this research, because in evaluating business success managers can take into account the differences in relation to the success of their competitors (Dawes, 1999, p. 67). Besides the effectiveness indicators, which are not always capable of including all the aspects of business success or independently measuring accurately all the efforts and results of organizational activities, such as various investments in research and development, as well as marketing, the use of multiple measures of organizational success is advised in order to avoid the bias of using exclusively the financial indicators, thus allowing a more thorough insight into business success. In line with the foregoing, a larger number of business success indicators was used (Wang, 2008, p. 3; Raisch \& Birkinshaw, 2008, p. 400). Hence, business success effectiveness was measured by comparing market share growth in the last three years, as well as by comparing net growth and sales growth of products/ services (Ravichandran \& Lertwongsatien, 2005, p. 248255; Raisch \& Birkinshaw, 2008, p. 400). All stated indicators were measured on a Likert-type scale ranging from 1 to 5 and the influence of organizational crisis preparedness on business success was analyzed by means of the PLS-SEM method. 


\section{TABLE 1: Measurement scale for business success with factor loadings}

\begin{tabular}{|l|c|c|}
\hline \multicolumn{2}{|l|}{ MEASUREMENT SCALE FOR BUSINESS SUCCESS } & \\
\hline $\begin{array}{l}\text { Question: please evaluate to which extent you agree with the following } \\
\text { statements: }(1=\text { I certainly do not agree, } 2=\text { I do not agree, } 3=\text { I do not } \\
\text { agree or disagree, } 4=\text { I agree, } 5=I \text { completely agree): }\end{array}$ & SYMBOL & $\begin{array}{c}\text { Factor } \\
\text { loadings }\end{array}$ \\
\hline $\begin{array}{l}\text { 1. Within the last three years, our firm's net gains were higher than that of our } \\
\text { competitors. }\end{array}$ & (EFI1) & 0.899 \\
\hline $\begin{array}{l}\text { 2. Within the last three years, our firm's return on sales (ROS) was higher than } \\
\text { that of our competitors. }\end{array}$ & (EFI2) & 0.891 \\
\hline $\begin{array}{l}\text { 3. Within the last three years, our firm's return on assets (ROA) was higher } \\
\text { than that of our competitors. }\end{array}$ & (EFI3) & 0.927 \\
\hline $\begin{array}{l}\text { 4. Within the last three years, our firm's return on investments (ROI) was } \\
\text { higher than that of our competitors. }\end{array}$ & (EFI4) & 0.926 \\
\hline $\begin{array}{l}\text { 5. Within the last three years, our firm's growth of net gains was higher than } \\
\text { that of our competitors. }\end{array}$ & (EFE1) & 0.887 \\
\hline $\begin{array}{l}\text { 6. Within the last three years, our firm's growth in sales of products/services } \\
\text { was higher than that of our competitors. }\end{array}$ & (EFE2) & 0.828 \\
\hline $\begin{array}{l}\text { 7. Within the last three years, our firm's growth in market share was higher } \\
\text { than that of our competitors. }\end{array}$ & (EFE3) & 0.821 \\
\hline
\end{tabular}

Source: Author

Note: $\mathrm{EFI}=$ efficiency, $\mathrm{EFE}=$ effectiveness

Variations in the dependent variable "business success" are partially explained by the level of organizational crisis preparedness. In order to evaluate the variations in dependent and independent variables, it is necessary to conceptualize, specify and operationalize the indicators. Variables in Table 2 were formed after researching crisis management literature, and seeking the most suitable means to viably measure a complex construct of organizational crisis preparedness through a research survey instrument. Hence, measures of organizational crisis preparedness will be used in accordance with verified measurement scales of the current and future perceived level of organizational crisis preparedness (Carmeli \& Schaubroeck, 2008, p. 184-185). The latent variable of organizational crisis preparedness consists of two latent first degree variables:

- the current crisis preparedness (the capabilities of an organization to respond to present crisis situations) and
- the prospective crisis preparedness (the capabilities of an organization to respond to future crisis situations).

A complete construct "Crisis Preparedness" from the research survey questionnaire Organizational Crisis Preparedness (Carmeli \& Schaubroek, 2008, p. 186) was applied. The construct consists of two factors - current crisis preparedness (with the initially tested Cronbach alpha value in their article of 0.87 , while the Cronbach alpha value in this paper was 0.934) and the "Prospective crisis preparedness" (with the initially tested Cronbach alpha value in their article of 0.84 while the Cronbach alpha value in this paper was 0.935). The Likert scale ranging from 1 to 5 was used to measure the questions as applied in this paper (from 1 - I certainly do not agree to 5 - I completely agree). 
TABLE 2: Measurement scale for organizational crisis preparedness with factor loadings

\begin{tabular}{|l|c|c|}
\hline \multicolumn{2}{|l|}{ MEASUREMENT SCALE FOR ORGANIZATIONAL CRISIS PREPAREDNESS (OCP) } & \\
\hline $\begin{array}{l}\text { Question: please evaluate to which extent you agree with the following } \\
\text { statements: ( } 1=\text { I certainly do not agree, } 2=\text { I do not agree, } 3=\text { I do not } \\
\text { agree or disagree, } 4=\text { I agree, } 5=\text { I completely agree): }\end{array}$ & SYMBOL & $\begin{array}{c}\text { Factor } \\
\text { loadings }\end{array}$ \\
\hline $\begin{array}{l}\text { 1. We are prepared for different types of crises. } \\
\text { 2. Our preparation scope to deal with a crisis is good. }\end{array}$ & (CCP1) & 0.792 \\
\hline $\begin{array}{l}\text { 3. We know which types of crisis we will be able to cope with without } \\
\text { severe damage. }\end{array}$ & (CCP3) & 0.825 \\
\hline $\begin{array}{l}\text { 4. We have good knowledge regarding the different phases of } \\
\text { organizational crises. }\end{array}$ & (CCP4) & 0.861 \\
\hline $\begin{array}{l}\text { 5. We know what to do at every possible phase of an organizational crisis. } \\
\text { 6. In a crisis situation, we know whether it is right to be reactive or proactive. }\end{array}$ & (CCP5) & 0.886 \\
\hline $\begin{array}{l}\text { 7. We would know how to diagnose the causes of a crisis. } \\
\text { 8. We would know what resources and quantities to allocate in order to } \\
\text { successfully cope with a crisis. }\end{array}$ & (PCP1) & 0.855 \\
\hline $\begin{array}{l}\text { 9. We would know how to detect and manage the needs and expectations } \\
\text { of the key constituents (stakeholders) in the crisis. }\end{array}$ & (PCP3) & 0.863 \\
\hline $\begin{array}{l}\text { 10. We would know how to diagnose changes in the needs of the } \\
\text { constituents (stakeholders) in the crisis. }\end{array}$ & (PCP4) & 0.787 \\
\hline
\end{tabular}

Note: $C C P=$ current crisis preparedness, $\mathrm{PCP}=$ prospective crisis preparedness

Source: Author's results, based on the scale in Carmeli \& Schaubroeck (2008)

Hypothesis 1, therefore, posits that improve- have a direct and positive effect on business ments in organizational crisis preparedness success of firms.

FIGURE 1: Proposed organizational crisis preparedness structural model

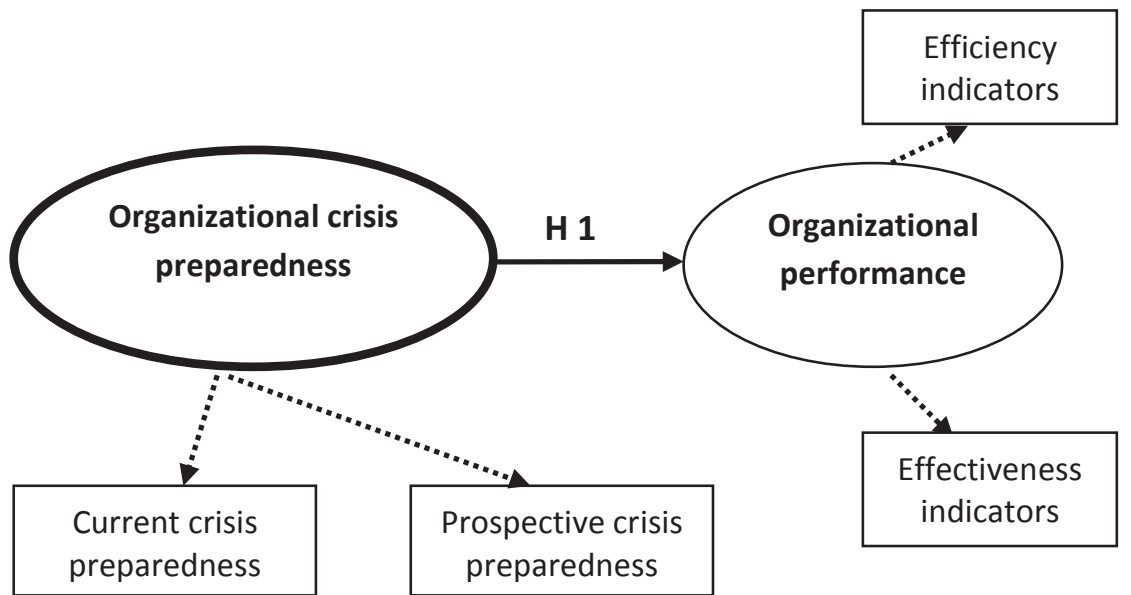




\section{ANALYSIS AND RESULTS}

A descriptive analysis of the sample yielded the results shown in Table 3.

TABLE 3: Sample descriptive statistics

\begin{tabular}{|c|c|c|}
\hline Attribute & Values & Percentage $\%$ \\
\hline $\begin{array}{l}\text { Firm's size (measured by } \\
\text { the number of employees) }\end{array}$ & $\begin{array}{c}\text { 1=Medium (<250 employees) } \\
\text { 2=Large (250 or more employees) }\end{array}$ & $\begin{array}{l}59,65 \% \\
40,35 \% \\
\end{array}$ \\
\hline $\begin{array}{l}\text { Respondents' hierarchical } \\
\text { position in the firm }\end{array}$ & $\begin{array}{c}\text { 1=CEOs, Board members } \\
2=\text { Directors of finance, controlling, strategic } \\
\text { planning, crisis managers } \\
3=\text { Other organizational functions }\end{array}$ & $\begin{array}{l}48 \% \\
31 \% \\
21 \%\end{array}$ \\
\hline \multirow{6}{*}{ Firm's age in years } & $1=0-5$ & $4 \%$ \\
\hline & $2=6-10$ & $8 \%$ \\
\hline & $3=11-19$ & $18 \%$ \\
\hline & $4=20-29$ & $26 \%$ \\
\hline & $5=30-50$ & $15 \%$ \\
\hline & $6=$ above 50 & $29 \%$ \\
\hline $\begin{array}{l}\text { Firm's previous significant } \\
\text { crisis experience }\end{array}$ & $\begin{array}{c}1=\text { Yes } \\
2=\text { No } \\
3=\text { Cannot answer }\end{array}$ & $\begin{array}{l}50 \% \\
37 \% \\
13 \% \\
\end{array}$ \\
\hline
\end{tabular}

Source: Author's research

For the item non-response bias, a complete case approach was used, with listwise deletion of all questionnaires which have not been fully completed or are lacking certain answers. Their exclusion from further analysis enables adequate comparability of research questions on all measurement parameters and is the recommended approach in SEM models (Kline, 2011, p. 57).

For the unit non-response bias, a wave analysis approach method was used to compare the responses of the respondents/managers in the first wave, as opposed to the responses of the respondents in the following waves, which served as a proxy for non-respondents (Zou, Andrus \& Norvell, 1997). The analysis was conducted by the independent samples t-test method in SPSS, where no statistically significant difference was found between the analyzed groups at the 5\% level of significance, meaning that the non-response bias was not statistically significant.
In order to test for the common method bias in the model, Pearson correlation matrix analysis of the latent constructs was conducted; correlations were lower than 0.9 values (Lowry \& Gaskin, 2014, pp. 137-138), which indicates the low possibility of common method bias being present.

Model testing consisted of two phases: preliminary data analysis, and structural model evaluation and hypothesis testing phase. Preliminary data analysis was performed by:

- descriptive statistical indicators analysis (minimum, maximum, arithmetic means and standard deviations analysis) and visual analysis of descriptive sample measures;

- $\quad$ testing of univariate and multivariate (by using the Mahalanobis distance) outliers;

- testing univariate normality of indicators through use of histograms; 
- testing of distribution normality for skewness and kurtosis.

Subsequently to the validation of preliminary data, factors were analyzed by:

- Principal Components Analysis (PCA), which was applied to gathered data for latent constructs. Latent (unobserved) variables represent multidimensional constructs, since they relate to several different variables which are observed as one theoretical concept, and each latent variable comprises corresponding multiple indicators (observable measures) (Hair, Black, Babin \& Anderson, 2010, p. 629-634).

- In testing PCA, the Kaiser Meier Olkin (KMO) test was used, as well as Barttlet's sphericity test for the evaluation of appropriateness for use of factor analysis.

- In PCA factor analysis, the Varimax method of factor rotation was applied and the eigenvalue rule was used for extracting factors with values greater than 1 according to Kaiser's rule, which was additionally verified by visually observing the Scree plot diagrams in order to determine the unidimensionality of constructs.

- Furthermore, metric characteristics of applied measurement scales were evaluated using the Cronbach alpha tests.

Such analyses were conducted prior to hypotheses testing in order to describe the main characteristics of gathered data and determine its appropriateness for PLS-SEM analyses. Also, the unidemensionality of every factor was tested in the SmartPLS statistical program; hence, the measurement model was evaluated through insight into factor loadings for each correspond- ing latent construct. In addition, reliability and validity analyses of the measurement model were conducted, where convergence testing took place (Cronbach alpha test, Composite reliability - CR, Average Variance Extracted - AVE), and discriminant validity was tested (by means of comparing AVE>coefficient of determination between the latent variables) before proceeding to structural model testing.

After the data was prepared and verified in the measurement model, determining that the data satisfied the convergent and discriminant validity, the hypothesis testing was done by analyzing the structural model in the next phase, where the multidimensional latent constructs and their causal relations were tested in the SmartPLS 2.0 M3 (Ringle, Wende \& Will, 2005) statistical program. For determining the relation in the structural equations model, an evaluation of the structural model was conducted:

- Collinearity analysis;

- $\quad$ R2 analysis of explained variance of endogenous variables;

- $\quad$ f2 analysis of the measure which evaluates the size of the extent to which exogenous variables have an influence on endogenous variables;

- Also, the bootstrap method was used to evaluate the significance of the influence of exogenous variables on endogenous variables, along with bootstrap confidence intervals.

- In analyzing the model, $Q^{2}$ and $q^{2}$ measures of predictive relevance were applied by using the blindfolding method for evaluation. 


\section{Direct causal influence analysis}

TABLE 4: Bootstrap structural coefficients analysis (standardized $\beta$ coefficients, $t$ values and $p$ values) for structural relations in proposed structural model

\begin{tabular}{|l|c|c|c|c|c|c|c|c|}
\hline Hypothesis & $\begin{array}{c}\text { Direction } \\
\text { relation }\end{array}$ & $\boldsymbol{\beta}$ & $\begin{array}{c}\text { Standard } \\
\text { error }\end{array}$ & $\begin{array}{c}\boldsymbol{t} \\
\text { value }\end{array}$ & $\begin{array}{c}\boldsymbol{p} \\
\text { value }\end{array}$ & $\begin{array}{c}\text { Lower } \\
\text { bootstrap } \\
\text { interval } \\
\text { bound }\end{array}$ & $\begin{array}{c}\text { Upper } \\
\text { bootstrap } \\
\text { interval } \\
\text { bound }\end{array}$ & $\begin{array}{c}\text { Hypothesis } \\
\text { confirmed }\end{array}$ \\
\hline H1 & OCP -> OP & 0.4309 & 0.0723 & 5.9595 & $0.0000^{*}$ & 0.2892 & 0.5726 & YES \\
\hline
\end{tabular}

Source: Author

Note 1: $p$-values were calculated by transforming t-values in MS Excel through order TDIST (with parameters 'degrees of freedom' $=$ number of respondents-1, i.e. 113 degrees of freedom, two-way distribution)

Note 2: $\mathrm{OCP}=$ organizational crisis preparedness, $\mathrm{OP}=$ organizational performance

Note 3: *significant results at $p<0.001, N S=$ not statistically significant

Having subjected Table 3 to bootstrap analysis, the standardized $\beta$ coefficients were tested by evaluating the $t$ test and corresponding $p$-values significance, where the results of the relationships (hypothesis) testing are as follows:

Regarding H1, organizational crisis preparedness (OCP) has a statistically significant positive influence on organizational performance (OP) ( $\beta=0.4309, p<0.001)$; hence, $\mathrm{H} 1$ is confirmed.

\section{CONCLUSION}

By researching the literature and, as yet, inadequately empirically tested constructs of organizational crisis preparedness in developing countries with its impact on business success, this paper confirmed the existence of a statistically significant correlation and influence of organizational crisis preparedness on the business success of medium and large-sized firms conducting their business in Croatia, a developing country, where the business success component was evaluated through indicators of effectiveness and efficiency. It also confirmed the positive influence, in this particular developing country, as that noted in earlier similar research conducted in developed countries (see Light, 2008; Carmeli \& Schaubroeck, 2008).
This article was of exploratory nature; its goal was to raise managerial awareness and stimulate managers to think about the organizational crisis preparedness implementation and improvement, where the key argument was that organizational crisis preparedness - as proved by the research results - directly contributes to business success. Therefore, since lots of firms are crisis prone and a few are truly crisis prepared, the results obtained stress the importance of adequately implementing organizational crisis preparedness, while also outlining that firms should take action. Accordingly, in order to succeed, the implementation of organizational crisis preparedness should be top managers' strategic responsibility and they, in turn, should be able to train and motivate their employees (Light, 2008, p. 28-47), rather than delegating this responsibility to designated middle management. Organizational crisis preparedness should be a continuously supported and funded activity by managers of medium and large-sized firms, in order to protect the organization and serve as both a measure and an indicator of excellence. One measure of improving organizational crisis preparedness and learning form mistakes is to encourage and award the employees for alerting and pointing to organizational weaknesses and mistakes 
(Weick, Sutcliffe \& Obstfeld, 1999). In order to improve organizational crisis preparedness, it is necessary to promote collective responsibility of all employees for crisis preparedness and environmental scanning (Carmeli \& Schaubroeck, 2008, p. 190).

In future studies, it is recommended to conduct the same or modified research in other developing countries in order to compare the results. It is also recommended to conduct any future research by specifying in advance the criteria for distinguishing successful from less successful firms to determine whether there are statistically significant differences among the two sub-groups with respect to crisis preparedness and its determinants. Another pos- sible direction of research is to focus on a single specific industry, where all firms face similar crisis challenges.

To conclude, organizational crisis preparedness positively impacts business success, as confirmed by the empirical results, and implicitly also competitive advantage. Understanding key organizational crisis preparedness variables allows advantages and savings of time, money, as well as a reduction of potential crisis damage which, consequently, results in a higher level of business success. Hence, in the content of the organizational culture, crisis management should be promoted, as should be the importance of sub-field of organizational crisis preparedness and employee readiness for crisis situations.

\section{References}

1. Anderson, J. C., \& Gerbing, D. W. (1988). Structural equation modeling in practice: a review and recommended two-step approach, Psychological Bulletin, 103(3), 411-423.

2. Auh, S., \& Menguc, B. (2005). Balancing exploration and exploitation: the moderating role of competitive intensity. Journal of Business Research, 58(12), 1652-1661.

3. Capstone Encyclopaedia of Business (2003). Crisis management. Available at: www.credoreference.com/entry/capstonebus/crisis_management (April 17, 2015.).

4. Carmeli, A., \& Schaubroeck, J. (2008). Organisational Crisis-Preparedness: The Importance of Learning from Failures. Long Range Planning, 41(2), 177-196.

5. Coombs, W. T., \& Holladay, S. J. (2006). Unpacking the halo effect: reputation and crisis management. Journal of Communication Management, 10(2), 123-137.

6. Coutu, D. L. (2002). How Resilience Works. Harvard Business Review, 80(5), 46-55.

7. Croatian Financial Agency- FINA, Available at: www.fina.hr

8. Dawes, J. (1999). The Relationship between Subjective and Objective Company Performance Measures in Market Orientation Research: Further Empirical Evidence. Marketing Bulletin, 10, 65-75.

9. Elsubbaugh, S., Fildes, R., \& Rose, B. M. (2004). Preparation for Crisis Management: A Proposed Model and Empirical Evidence. Journal of Contingencies and Crisis Management, 12(3), 112-127.

10. Federal Emergency Management Agency - FEMA (2011). Business Continuity and Disaster Preparedness Planning Patterns and Findings from Current Research, Citizen preparedness review: Community Resilience through Civic Responsibility and Self-Reliance, 7, 1-21.

11. Fink, S. (1986). Crisis Management. New York, NY: American Management Association AMACOM.

12. Fowler, K. L., Kling, N. D., \& Larson, M. D. (2007). Organizational preparedness for coping with a major crisis or disaster. Business \& Society, 46(1), 88-103.

13. Greyser, S. A. (2009). Corporate brand reputation and brand crisis management, Management Decision, 47(4), 590-602.

14. Guderang, S. G., Ringle, C. M., Wende, S., \& Will, A. (2008). Confirmatory tetrad analysis in PLS path modeling. Journal of Business Research, 61(12), 1238-1249. 
15. Haenlein, M., \& Kaplan, A. M. (2004). A Beginner's Guide to Partial Least Square Analysis. Understanding statistics, 3(4), 283-297.

16. Hair, J. F., Ringle, C. M, \& Sarstedt, M. (2011). PLS-SEM: Indeed a Silver Bullet. Journal of Marketing Theory and Practice, 19(2), 139-151.

17. Hair, J. F., Sarstedt, M., Ringle, C. M., \& Mena, J. A. (2012). An Assessment of the Use of Partial Least Squares Structural Equation Modeling in Marketing Research. Journal of the Academy of Marketing Science, 40(3), 414-433.

18. Hair, J. F., Black, W. C., Babin, B. J., \& Anderson, R. E. (2010). Multivariate Data Analysis: A Global Perspective. New Jersey, NJ: Pearson Education.

19. Hale, J. E., Dulek, R. E., \& Hale, D. P. (2005). Crisis Response Communication Challenges: Building Theory from Qualitative Data. Journal of Business Communications, 42(2), 112-134.

20. James, E. H., Wooten, L. P., \& Dushek, K. (2011). Crisis Management: Informing a New Leadership Research Agenda. The Academy of Management Annals, 5(1), 455-493.

21. Jaques, T. (2010). Reshaping crisis management: the challenge for organizational design. Organizational Development Journal, 28(1), 9-17.

22. Kline, R. B. (2011). Principles and Practices of Structural Equation Modeling. $3^{\text {rd }}$ ed. New York, NY: The Guilford Press.

23. Kraft, K. (1990). Are product and process innovations independent of each other?. Applied Economics, 22(8), 1029-1038.

24. Kunc, M., \& Bhandari, R. (2011). Strategic development processes during economic and financial crisis. Management Decision, 49(8), 1343-1353.

25. Lalonde, C. (2007). Crisis management and organizational development: towards the conception of a learning model in crisis management. Organization Development Journal, 25(1), 17-26.

26. Lee, J., Woeste, J. H., \& Heath, R. L. (2007). Getting ready for crises: strategic excellence. Public Relations Review, 33(3), 334-336.

27. Light, P. C. (2008). Predicting organizational crisis readiness: perspectives and practices toward a pathway to preparedness. New York University, NY: The Center for Catastrophe Preparedness and Response.

28. Lowry, P. B., \& Gaskin, J. (2014). Partial Least Squares (PLS) Structural Equation Modeling (SEM) for Building and Testing Behavioral Causal Theory: When to Choose It and How to Use It. IEEE Transactions on Professional Communication, 57(2), 123-146.

29. March, J. G., \& Sutton, R. I. (1997). Organizational Performance as a Dependent Variable. Organizational Science, 8(6), 698-706.

30. McDougall, P. P., Covin, J. G., Robinson, R. B., \& Herron, L. (1994). The effects of industry growth and strategic breadth on new venture performance and strategic content. Strategic management Journal, 15(7), 537-554.

31. Mikušova, M., \& Horvathova, P. (2011). The Research Approaches on Crisis and its Management. Proceedings of World Academy of Science, Engineering and Technology, 73, 610-618.

32. Monecke, A., \& Leisch, F. (2012). SEM-PLS: Structural Equation Modeling Using Partial Least Squares. Journal of Statistical Software, 48(3), 1-32.

33. Nystrom, P. C., \& Starbuck, W. H. (1984). To avoid organizational crises, unlearn. Organizational Dynamics, 12(4), 53-65.

34. Parnell, J. A., Koseoglu, M. A., \& Spillan, J. E. (2010). Crisis Readiness in Turkey and the United States. Journal of Contingencies and Crisis Management, 18(2), 108-116.

35. Pearson, C., \& Clair, J. (1998). Reframing crisis management. Academy of Management Review, 23(1), 59-76.

36. Pearson, C., \& Sommer, A. (2011). Infusing creativity into crisis management: An essential approach today. Organizational Dynamics, 40(1), 27-33. 
37. Pforr, C., \& Hosie, P. J. (2008). Crisis Management in Tourism. Journal of Travel \& Tourism Marketing, 23(2/4), 249-264.

38. Probst, G., \& Raisch, S. (2005). Organizational crisis: The logic of failure. Academy of Management Executive, 19(1), 90-105.

39. Raisch, S., \& Birkinshaw, J. (2008). Organizational Ambidexterity: Antecedents, Outcomes, and Moderators. Journal of Management, 34(3), 375-409.

40. Ravichandran, T., \& Lertwongsatien, C. (2005). Effect of Information Systems Resources and Capabilities on Firm Performance: A Resource-Based Perspective. Journal of Management Information Systems, 21(4), 237-276.

41. Reilly, A. H. (1993). Preparing for the worst: the process of effective crisis management. Industrial and Environmental Crisis Quarterly, 7(2), 115-143.

42. Reilly, A. H. (1987). Are organizations ready for crisis? A managerial scorecard. The Columbia Journal of World Business, 22, 79-88.

43. Ringle, C. M., Wende, \& S., Will, A., (2005) SmartPLS, vol. 2011. SmartPLS. Hamburg. Available at: www.smartpls.de (January 27, 2014).

44. Ritchie, B. W. (2004). Chaos, crises and disasters: a strategic approach to crisis management in the tourism industry. Tourism Management, 25(6), 669-683.

45. Rousaki, B., \& Alcott, P. (2007). Exploring the Crisis Readiness Perceptions of Hotel Managers in UK. Tourism and Hospitality Research, 7(1), 27-38.

46. Roux-Dufort, C. (2009). The Devil Lies in Details! How Crises Build up Within Organizations. Journal of Contingencies and Crisis Management, 17(1), 4-11.

47. Santos-Vijande, M. L., Lopez-Sanchez, J. A., \& Trespalacios, J. A. (2012). How organizational learning affects a firm's flexibility, competitive strategy, and performance. Journal of Business Research, 65(8), 1079-1089.

48. Sapriel, C. (2010). Why do we keep making the same mistakes?. Communication World, 27(4), 28-30.

49. Selart, M., \& Johansen, S. T. (2013). Employee Reactions to Leader-Initiated Crisis Preparation: Core Dimensions. Journal of Business Ethics, 116(1), 99-106.

50. Shaw, D., Hall, M., Edwards, J. S., \& Baker, B. (2007). Responding to crisis through strategic knowledge management. Journal of Organizational Change Management, 20(4), 559-578.

51. Shaw, G. L. (2004). The competencies required for executive level business crisis and continuity managers. Doctoral Dissertation. Washington, D.C.: George Washington University.

52. Smith, D. (1990). Beyond contingency planning: towards a model of crisis management. Industrial Crisis Quarterly, 4(4), 263-275.

53. Spillan, J. E., Parnell, J. A., \& Mayolo, C. A. (2011). Exploring Crisis Readiness in Peru. Journal of International Business and Economy, 12(1), 57-83.

54. Tucker, L., \& Melewar, T. C. (2005). Corporate reputation and crisis management: The threat and manageability of anti-corporatism. Corporate Reputation Review, 7(4), 377-387.

55. Valackie, A. (2010). Efficient Corporate Communication: Decisions in Crisis Management. Commerce of Engineering Decisions, 21(1), 99-110.

56. Veil, S. R. (2011). Mindful Learning in Crisis Management. Journal of Business Communication, 48(2), 116-147.

57. Wang, W-T. (2008). Measuring Organization's Crisis Management Performance: An Exploratory Study, 1-22. Available at: http://academic-papers.org/ocs2/session/Papers/B8/136-1486-1-DR.doc (August 9, 2015).

58. Weick, K. E., Sutcliffe, K. M., \& Obstfeld, D. (1999). Organizing for high reliability: Processes of collective mindfulness. In: B. M. Staw \& L. L. Cummings (Eds.). Research in organizational behavior (pp. 81-123). Greenwich, CT: JAI Press, Inc. 
59. Wetzels, M., Oderken-Schroder, G., \& van Oppen, C. (2009). Using PLS Path Modeling for Assessing Hierarchical Construct Models: Guidelines and Empirical Illustration. MIS Quarterly, 33(1), 177-195.

60. Wilden, R., Gudergan, S. P., Nielsen, B. B., \& Lings, I. (2013). Dynamic Capabilities and Performance: Strategy, Structure and Environment. Long Range Planning, 46(1/2), 72-96.

61. Wong, K. K-K. (2013). Partial Least Squares Structural Equation Modeling (PLS-SEM) Techniques Using SmartPLS. Marketing Bulletin, 24, 1-32.

62. Wooten, L. P., \& James, E. H. (2008). Linking Crisis Management and Leadership Competencies: The Role of Human Resource Development. Advances in Developing Human Resources, 10(3), 352-379.

63. Zou, S., Andrus, D. M., \& Norvell, D. W. (1997). Standardization of international marketing strategy by firms from a developing country. International Marketing Review, 14(2), 107-123. 